\title{
Students' Problem-Solving Profile in Overcoming Sound Wave Concepts Based Students' Academic Abilities on Online Class
}

\author{
Iron Ujulu ${ }^{1}$, Masri K. Umar ${ }^{2}$, Mursalin², and Abdul Haris Odja ${ }^{2, *}$ \\ ${ }^{1}$ A student of master of physics education program, Universitas Negeri Gorontalo, Jend. Sudirman street, \\ Number 06, Gorontalo 96128, Indonesia. \\ ${ }^{2}$ A lecture of master of physics education program, Universitas Negeri Gorontalo, Jend. Sudirman street \\ Number. 06, Gorontalo 96128, Indonesia \\ *Corresponding author. Email: abdul.haris.odja@gmail.com
}

\begin{abstract}
A research has been conducted to describe the students' initial problem-solving abilities through five stages of problem-solving. This study was aim to describe the profile of students' problem-solving in overcoming sound wave concepts in terms of academic ability, where the research subjects were grade XI students of SMA Negeri 6 Gorontalo Utara. It was a part of the research development of social media-aided named blended learning models to improve problem-solving skills. It used qualitative descriptive study it shows percentage of problem-solving ability test completion stages is in the category of students with academic abilities, with an average score of $83.75 \%$, after that students are in the medium and low categories. It showed that there are some who are able to carry out the stages of problem-solving in completing problem-solving tests but have not been able to describe it properly. Finally, the maximum score was difficult to get either in students with high, medium and low academic ability categories.
\end{abstract}

Keywords: Blended learning, problem-solving, academic abilities.

\section{INTRODUCTION}

Problem-solving is one of the important abilities that must have by students. It is a person's ability to find solutions through a process that involves obtaining and organizing information [1]. it involves finding a viable way to achieve the goal [2].

There are many previous studies that attempted to improve the problem-solving abilities of students through various learning strategies. In some of these studies, it shows the low ability of students to solve problems which probably caused by several things including learning patterns and the use of media to support learning. The low problem-solving skills are caused by several factors including science learning that more oriented to textbooks and more traditional laboratory activities [3]. Furthermore, it stated that students are more concern to solve structured problems rather than unstructured [3]. To increase the ability of solving problems in physical material, we can use several indicators including: (1) visualizing or describing the problem; (2) physics approach; (3) applying physics concepts; (4) mathematical procedure; and (5) logically conclude the problem [4].

Problem-solving abilities cannot be separated with the structure of students' knowledge. In the process of it, they need knowledge from previous experiences, both from face-to-face online learning experiences with the help of social media. In accordance with the view of constructivist learning theory, learning is not just a process of knowledge transfer but about it is how 
to construct knowledge by connecting their initial knowledge with the experience they just gained [5].

The effort to know the problem-solving abilities of students in physics, it is necessary to have learning innovations to support the achievement of learning objectives. In addition, during the current Covid-19 pandemic, learning innovations are expected to take advantage of technology, one of which is the WhatsApp social media. The use of instructional media has a specific purpose to assist in the teaching and learning process. The general purpose of using media is to increase effectiveness and efficiency in teaching and learning activities. The specific objectives of using the media are: (1) to support class activities; (2) encouraging the use of appropriate methods to achieve the objectives of the academic program; and (3) assist, provide planning, production operations and follow-up to develop instructional systems [6].

Physics is a very interesting subject to discuss using social media. However, so far physics lessons are still difficult to learn because they are still abstract, causing low problem-solving abilities. Instruments are needed to measure the problem-solving abilities of students in physics by optimizing the use of social media in supporting the implementation of learning.

The developed instrument in this study focuses on sound wave material. The problem-solving ability test was developed based on five indicators of problemsolving ability adapted from Heler and Heller. This design consists of five stages of problem-solving,
[7]. The indicators and guidelines for scoring problemsolving as in table 1 below.

\section{EXPERIMENTAL METHOD}

This research used mixed method that combines quantitative and qualitative methods. The chosen strategy was a sequential explanatory strategy. That strategy explains and interprets quantitative results based on the results of qualitative data collection and analysis. The instrument developed measures the students' physics problem-solving ability in the form of tests. in this case, the test is multiple choice but the answer is presented in the form of an essay to analyse the stages of solving the problem in each item. This type of question can measure the problem-solving ability as a whole, because it involves developing perceptions and reasoning. The subjects in this study were 20 students of class XI SMA Negeri 6 Gorontalo Utara, Gorontalo Province and the data analysed were students' answers to the multiple choice test which was completed based on essay completion. Furthermore, student answers are analysed based on indicators of problem-solving stages per item to measure student achievement in completing tests according to problem-solving, the data is then analysed or described based on the category of academic ability. this is done to compare students' academic abilities to the ability to solve problem-solving tests.

Table 1. Problem-solving guidlines

\begin{tabular}{|c|c|c|c|c|c|}
\hline \multirow{2}{*}{ score } & \multicolumn{5}{|c|}{ Problem-solving criteria } \\
\cline { 2 - 6 } & Problems & $\begin{array}{c}\text { Physical } \\
\text { description }\end{array}$ & Planning & Implementation & Evaluation \\
\hline $\mathbf{0}$ & unknown & none & None plan & No progress & None \\
\hline $\mathbf{1}$ & $\begin{array}{c}\text { Less } \\
\text { Interpretation } \\
\text { of question }\end{array}$ & $\begin{array}{c}\text { Know few } \\
\text { variables }\end{array}$ & $\begin{array}{c}\text { Mathematical } \\
\text { equations are not } \\
\text { related }\end{array}$ & $\begin{array}{c}\text { Mathematics } \\
\text { mistake founding }\end{array}$ \\
\hline $\mathbf{2}$ & $\begin{array}{c}\text { Understanding } \\
\text { the problems }\end{array}$ & $\begin{array}{c}\text { incomplete } \\
\text { view }\end{array}$ & $\begin{array}{c}\text { Mathematics } \\
\text { equations are } \\
\text { related }\end{array}$ & Finished but incomplete & Stuck \\
\hline $\mathbf{3}$ & & completing & & Finished and completed & $\begin{array}{c}\text { finished but } \\
\text { incorrect } \\
\text { manipulates the } \\
\text { number }\end{array}$ \\
\hline $\mathbf{4}$ & $\mathbf{2}$ & $\mathbf{3}$ & $\mathbf{2}$ & $\begin{array}{c}\text { Complete and continuing } \\
\text { the solving }\end{array}$ & $\begin{array}{c}\text { Finish and done } \\
\text { completely }\end{array}$ \\
\hline $\begin{array}{c}\text { Max } \\
\text { score }\end{array}$ & & & $\mathbf{4}$ & $\mathbf{4}$ \\
\hline
\end{tabular}

namely: (1) focusing on the problem, (2) describing it physically, (3) planning the solution, (4) implementing the completion plan, and (5) evaluating the solution 


\section{RESULT AND DISCUSSION}

The research was conducted through the stages of the problem-solving ability test and guidelines for evaluating students' answers based on the indicators that adapted from Heller, et.al. The data was obtained based on the test results, multiple choice type test was given, but it was solved based on the essay method. The data were analyzed based on the level of students' academic abilities. The academic ability of physics scores during the learning process in the classroom either accumulated per semester or in each particular exam. This is divided into: a) The upper group, for students with a value of $\geq 75, b$ ) the middle group, for students with a value of $50-74$, and c) the lower group, for students with a value of $\leq 49$ and for completion based on stages solution to problem. From the test results, it shows that most students have been able to complete the test based on the problem-solving stages.

Problem-solving result along with subjects' interview transcript.

\subsection{The upper group is students with a value $\geq 75$}

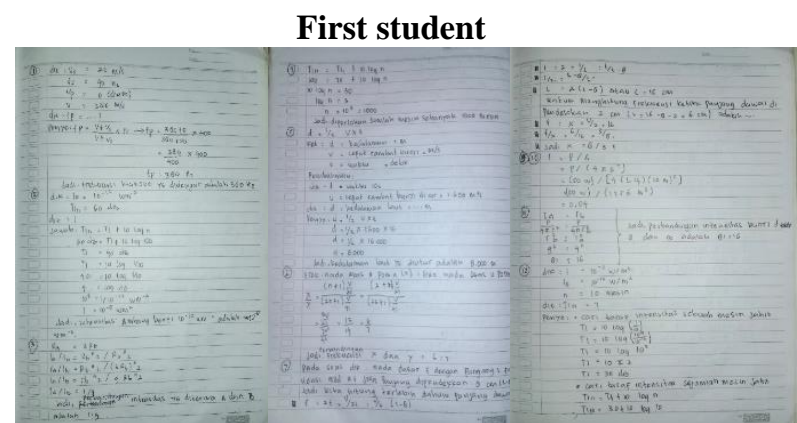

Figure 1. Problem-solving result of high ability category students.

The students' results tests on high academic categories showed that they can solve problems with stages based on the indicators. one stage of the physics Figure was not carried out and the problem-solving stage were not described completely. Students have been able to write down all things that are known in the questions completely, focus the problem, plan problem-solving, execute problems and evaluate the answers to the results.

Apart from the written test, an online interview held where the subject stated that the stages of problem-solving were not completely described, the final result of the problem-solving was still a benchmark in the assessment. However, the subject understands well in these stages. Furthermore, the results of problem-solving carried out by student 2 are as follows.

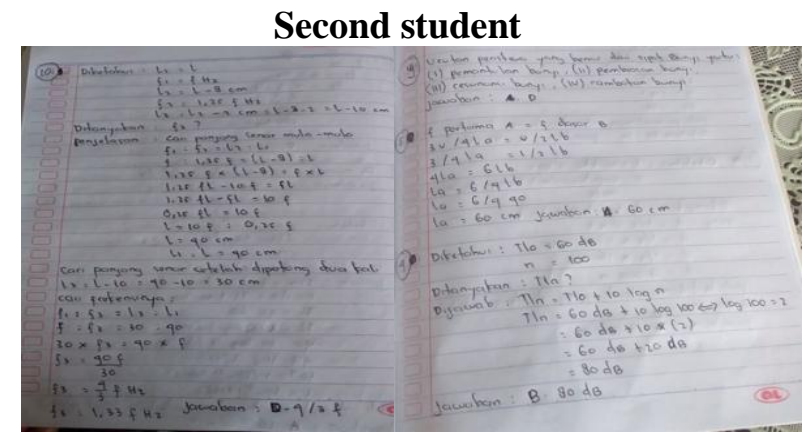

Figure 2. Problem-solving result of high ability category students

The Result shows that second student does not understand the problem well. It presents the lack, few things written as known on the problem and evaluate the answers of the results. Students in the category of high academic ability, but in terms of solving problemsolving tests have not been able to complete based on these stages.

Interviews were conducted through the courage associated with the completion of the test. The subject stated that the remaining stages of the problem were not described completely. it took a few minutes to complete the questions. This causes the second students unable to be on time to finish the test. Furthermore, he explained that he did not know clearly how these stages were and so far in terms of solving the physics test, it was just like solving in general. However, students 2 understand well in these stages.

\subsection{Middle group with the value $50-74$}

\section{Third student}

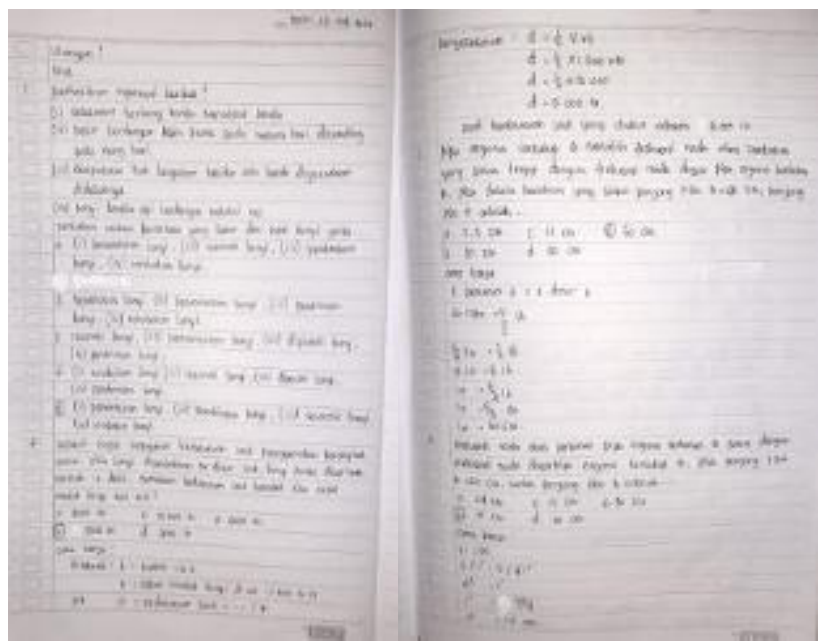

Figure 3. Problem-solving result of medium ability category students.

Third student are as the medium category in solving problem test questions got score 75 . This student wrote down everything he know completely, focus on problems, plan problem-solving, execute problems and evaluate the answers well. However, He could not explain in the completion of the test based 
on these stages. Students 3 are also the same as others, which have not described the questions in physics and completed the test based on completion generally.

An online interview to confirm the test results, the third students stated that he entered the problemsolving test earlier than the specified time. So, he still have plenty of time to complete the test and even have time to do a Google search and related to the problemsolving stages. He did not understand how to complete the test based on these stages. While the results of the subject 4 problem-solving test are as follows.

\section{Fourth student}

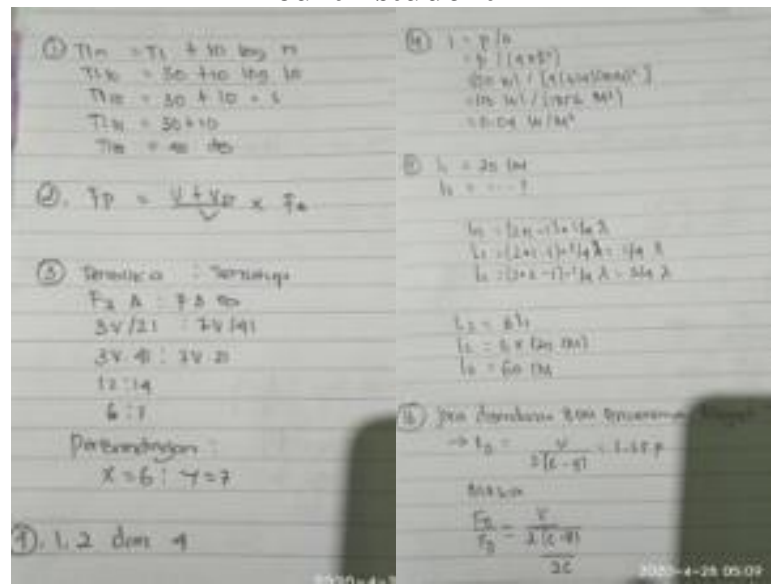

Figure 4. Problem-solving result of medium ability category students.

Based on the results of the test conducted, the fourth student was in middle category academic ability. In the test, he can understand the problem well but solve 3 questions only and could not do describing physics, the stage of planning the problem-solving, the stage of executing the problem so that the results obtained are less precise. Here are the following transcripts from the fourth student's interview. he stated his inability to complete a problem-solving test. This is due to the lack of understanding of physics material generally.

\subsection{The lower group with the value $\leq 49$}

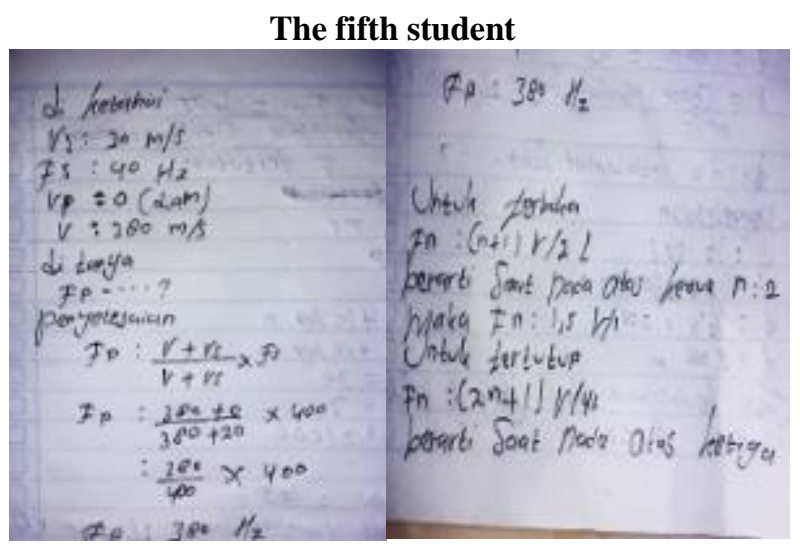

Figure 5. Problem-solving result of low ability category students.

The fifth Student is in low category; he could not complete the problem-solving test and got total score of 15. In some questions, he just completes the last stage of the problem-solving test, namely evaluation of answers. Some questions acquire the correct points but without the stages of solving the problem so the score are still less. While the results of the student problem-solving test 6 are as follows.

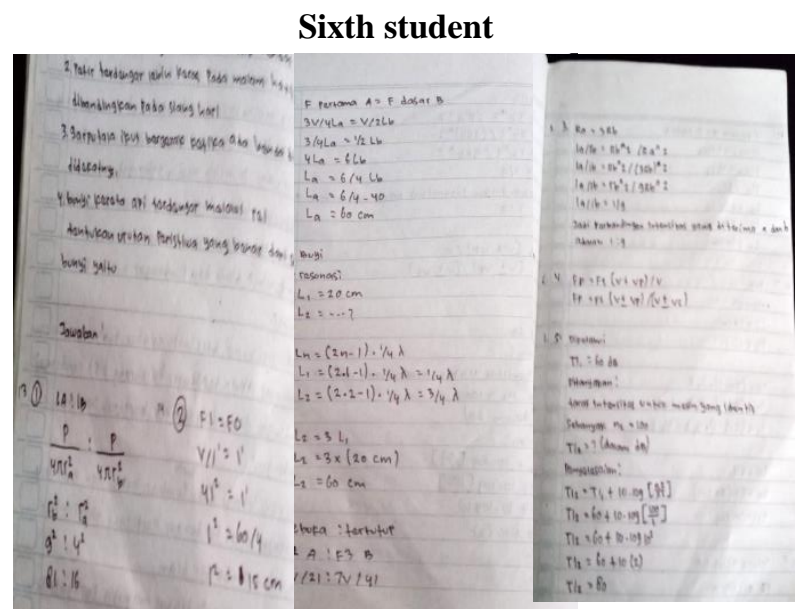

Figure 6. Problem-solving result of low ability category students.

The sixth student is in low academic ability to solve problem. He did not passed the test with following structural steps so his answers in the test was incorrect. In the interview, the fifth and sixth students stated that they did not understand and have no clue to answer the question properly. From that obstacle, they only can get the low scores.

From the overall results to the problem-solving tests and interviews that have been conducted, there are some who are able to carry out the stage in solving the problem-solving test but have not been able to describe it properly so that they could not get the maximum score. To determine the wetness of the findings, they are presented in the form of a result table as follows.

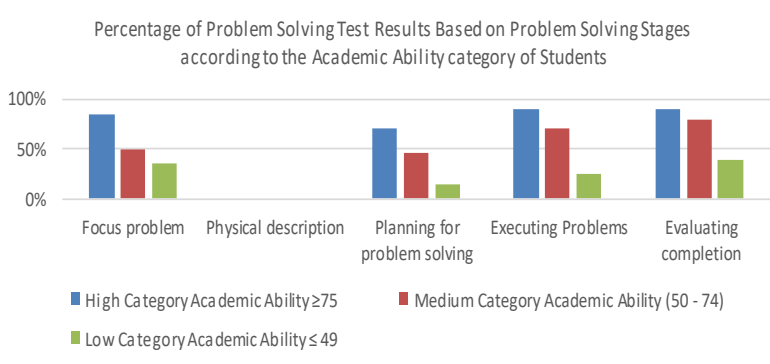

Figure 7. Problem-solving result 
Based on the results in the table above, it shows that the highest percentage of problem-solving ability test completion stages is in the category of students with academic abilities, with an average score of $83.75 \%$, after that students are in the medium $49.2 \%$ and low categories $23 \%$. However, all categories have not carried out the stages of describing it physically, but as a whole it can be seen that the comparison of the categories high category academic ability, medium category academic ability and low category academic ability to the four aspects of problem-solving is directly proportional. This finding is in line with research from Pratiwi, Samparadja, Arapu (2019: 54) explaining that the level of academic potential of students also has an influence on higher thinking skills, high thinking abilities of students with high academic potential are different from students with medium and low academic potential. . Theoretically, academic potential indicates a person's thinking ability profile so that students with high academic potential have high thinking skills as well [8].

\section{CONCLUSION}

Based on the results and discussion previously, it can be concluded that.

1. Students with high academic abilities are able to solve problem-solving tests with problemsolving stages well but have not fully explained them in solving the test either in focusing problems, describing physics, planning problemsolving, executing problems and evaluating answers.

2. Students with moderate or middle academic ability have not been able to complete the problem-solving ability test appropriately, it affects the stage of implementing the plan so that the results obtained are not right.

3. Students with a low academic ability category and in solving problem-solving tests did not carry out the problem-solving stages properly so that the results obtained were wrong.

Overall, it can be seen that the highest percentage of students' initial problem-solving ability test completeness is in the category with academic ability, with an average score of $83.75 \%$, after that students are in the medium category of $49.2 \%$ and the low category of $23 \%$.

\section{ACKNOWLEDGMENTS}

My deepest Thank to all those who have helped in completing this research, Directorate of Research and Community Service Ministry of Research and Technology/National Agency for Research and Innovation, UNG Postgraduate Leaders, Heads and Teachers and Students at SMAN 6 Gorontalo Utara and other parties who help this research.

\section{REFERENCES}

[1] Sujarwanto, E., Hidayat. \& Wartono. 2014. Kemampuan Pemecahan Masalah Fisika dan Modeling Instruction pada Siswa SMA Kelas XI. Jurnal Pendidikan IPA Indonesia (Online). 3(1). 65-78.

(https://media.neliti.com/media/publications/ 121601-ID-kemampuan-pemecahan-masalahfisika-pada.pdf, Diakses 7 Juli 2020).

[2] Santrock, J.W. 2014. Psikologi Pendidikan. Jakarta: Salemba Humanika

[3] Odja, A. H, Jatmiko, B., \& Supardi, Z.A. I. 2014. Model Konseptual Observasi Ilmiah Berorientasi Kemandirian Dalam Pembelajaran Sains Untuk Melatihkan Keterampilan Pemecahan Masalah. Surabaya.

[4] Suana, W., Raviany, M. \& Sesunan, F. 2019. Blended Learning Berbantuan Whatsapp:Pengaruhnya Terhadap Kemampuan Berpikir Kritis Dan Kemampuan Pemecahan Masalah. Jurnal Ilmiah Penelitian dan Pembelajaran Fisika. Vol. 5, No. 2. 37-45

[5] Arends, R.I. (1997). Learning to teach. New York: The Mc. Graw-Hill Company

[6] Djamarah, S. B \& Zain, A. 2013. Strategi Belajar Mengajar. Jakarta: PT. Rineka Cipta

[7] Heller, K., \& Heller, P. (2010). Cooperative problem-solving in physics a user's manual. National science foundation, university of minnesota, and u.s. department of education

[7] Heller, P., \& Heller, K. (1999). Cooperative group problem in physics. University of Minnesota

[8] Pratiwi, H., Samparadja, H., Arapu. (2019). Pengaruh Model Pembelajaran Terhadap Kemampuan Berpikir Kritis Ditinjau Dari Potensi Akademik Peserta Didik Kelas Xi Sma Negeri 1 Kendari. Jurnal Penelitian Pendididikan Matematika Volume 7 No.2 Mei 2019. FKIP Universitas Halu Oleo. 